\title{
Relationship of School Leadership with School Outcomes: A Meta-Analysis Study
}

\author{
Hasan Yücel Ertem ${ }^{1}$ \\ ${ }^{1}$ Ereğli Faculty of Education, Zonguldak Bülent Ecevit University, Zonguldak, Turkey \\ Correspondence: Hasan Yücel Ertem, Ereğli Faculty of Education, Zonguldak Bülent Ecevit University, \\ Zonguldak, Turkey. E-mail: hyertem@gmail.com
}

Received: December 27, 2020

Accepted: February 18, 2021

Online Published: April 25, 2021

doi:10.5539/ies.v14n5p31

URL: https://doi.org/10.5539/ies.v14n5p31

\begin{abstract}
Administration and governance of schools in Turkey have a complex structure and process. Within the centralized structure, the procedures in educational activities are managed by school principals. In the Turkish literature, there are studies showing leadership styles of school leaders based on the leadership theories borrowed from different contexts. Furthermore, these leadership styles are linked to school outcomes like academic achievement and teacher motivation. Thus, catching compatible sides of leadership theories may serve to improve this kind of school outcomes. In these respects, the current study aimed to investigate which leadership styles have more effect on academic achievement and teacher motivation. Exclusion and inclusion criteria were determined in order to identify the studies to be analyzed. A meta-analysis study including 21 studies in Turkish context was conducted to achieve the purpose of the study. The meta-analysis results showed that the leadership styles were highly related with the school outcomes. Overall, laissez-faire, transactional, instructional, and transformational leadership styles had a high and positive relation with the school outcomes. The laissez-faire and spiritual leadership styles showed more effect on the teacher motivation while the positive and transformational style had more effect on the academic achievement. Considering the conclusions of the study, it is recommended that future studies develop a leadership theory specific to the educational settings in Turkey.
\end{abstract}

Keywords: leadership, meta-analysis, teacher motivation, academic achievement, school outcomes

\section{Introduction}

\subsection{Background of the Problem}

In the human life, different periods shape the people socially, emotionally, and physically. While strong people established dominance on weak ones in earlier eras, qualified people with skills have gained the control over unqualified ones in the knowledge era. In other words, physical force has been replaced by knowledge, and education has become the core of this power balance.

Because of these developments, all countries attach great importance to education. Especially developed countries are aware of the fact that education system is a key factor for economic growth (Barro, 2013). Therefore, they make huge investments in their education quality. Education quality refers to fitness for use, the satisfaction of the needs of school elements, and conformance to these strategic elements' requirements and expectations (Cheng \& Tam, 1997). As a result, these investments in developed countries return as achievements in science and arts. On the other hand, undeveloped or $3^{\text {rd }}$ world countries give an emphasis on leadership but they generally support from leadership approaches of countries having their original leadership perspectives.

Turkey, as a developing country, could not catch the quality of education in the developed countries. Although Turkey has significantly succeeded in terms of educational quantity such as the number of higher education institutions, number of teachers, and schooling rates; it has not been able reach the level of other OECD countries in terms of educational quality like academic achievement (OECD, 2017). One of the main reasons for this is the instability in the Turkish education system, which is the result of the fact that there has been an administration problem in education in Turkey. In the Turkish education history, education has not been seen as a supra-political parties issue (Gedikoğlu, 2005). Every Minister of National Education fundamentally changes the education system or different governments give harm to educational administration. Not only macro-, but also micro-level institutions like schools have had similar administrative problems. The root of problems lies in school leadership. 


\subsection{Importance of the Problem}

School leaders have to take responsibility and adapt their organizations to the changing environment. According to Lynch (2012), leadership is pretty much related to the concrete results such as increased student performance, work ethics and motivation for staff. There are also many studies showing the effect of leadership on positive educational outcomes (Aydın, Sarıer, \& Uysal, 2013; Connelly et al., 2000; Demirdağ, 2015; Erdoğan, Kraimer, \& Lieden, 2004; Keung, Rockinson, \& Szapkiw, 2012; Moss \& Barbuto, 2010; Schuh, Zhang, \& Tian, 2013). In sum, leadership is an important issue to get a better education system and Turkey needs quality school leaders to build a sound education system.

School leadership in Turkey is a duty, not a job. It is perceived as a duty given rather than a professional job. For this reason, school leaders are selected from among teachers through some processes like written and oral exams. There is no department designed to award school leader diploma in universities. However, educational administration is a graduate level program for teachers and school principals to develop themselves in the field of administration. In Turkey, the course content of these programs depends heavily on U.S. and western context, which is the point where the problem begins. Turkey does not have its own original leadership perspective.

National literature also presents many studies investigating leadership styles in Turkey. To name a few, ethical leadership (Demirdağ, 2016; Altay \& Dedeoğlu, 2016), instructional leadership (Şişman, 2016), and distributed leadership (Baloğlu, 2016) were reported to increase the educational quality. In fact, leadership theories or approaches like transformational, distributed, and instructional leadership emerged in a different context. Moreover, leadership was examined within 21. Century skills, communication, and leadership styles (Elekoğlu \& Demirdağ, 2020). On the other hand, meta-analysis studies (Çoğaltay, Karadağ, \& Öztekin, 2014; Ünal, 2017) mostly concentrated on the effect of only one leadership theory, especially the transformational leadership. Furthermore, Sarier (2013) conducted a meta-analysis study and found that $54.6 \%$ of the studies were related to only a single leadership approach. As a result, the literature in Turkey lacks a comprehensive picture of school leadership.

In these respects, the current study has significance in terms of research, theory, and practice. In terms of research, this study will try to fill a gap in the literature by examining which borrowed theories reflect the Turkish school leaders in a more comprehensive way. The findings of this meta-analysis study may contribute to the theory by revealing the most remarkable characteristics of Turkish school leaders. And finally, policy-makers and educational administrators may develop strategies to increase the quality in schools by considering different leadership styles in terms of practice.

\subsection{Relevant Scholarship}

Leadership is related to improving how people present themselves to others. Organizations give importance to the leadership ability because of the special assets provided by leaders to the organization. Schools can be considered as organizations, and school leadership contains a variety of duties and responsibilities (Preedy, Bennett, \& Wise, 2012). School principals deal with both internal and external factors in leading the organizations. The internal ones are related to certain educational objectives while the external ones are related to imposition from outside school such as government or other official institutions. For successful leadership, it is very important to establish a link between aims, strategy, and operational management. Goal setting in education has three aspects. The first one is the formal goal in which physical, social, intellectual and moral qualities of students are important. The second is the organizational or individual goal. The third is the process of setting these goals by principals or stakeholders. In most cases, while setting goals, government may disregard the needs of students and schools. At this point, school leaders are able to modify government policies and develop alternative approaches for creating a school vision.

There are many leadership approaches but it is possible to classify them into four categories in order of chronology: characteristics approach, behavioral approach, situational approach, and contemporary approach. To begin with, characteristics approach assumes that certain characteristics create great leaders (Northouse, 2004). Trait and skill approaches are evaluated under the characteristics approach. Stodgill (1948), Mann (1959), Lord et al. (1986), and Kirkpatrick and Locke (1991) tried to find the traits that leaders differ from non-leaders. To name a few, intelligence, alertness, insight, extroversion, self-confidence, and integrity were asserted to be the traits specific to leaders. On the other hand, Katz (1955) put forward the three-skill approach consisting of technical, human, and conceptual skills while Mumford, Saccaro, Harding, Jakobs, and Fleishman (2000) modelled a skill approach consisting of individual attributes, competencies, and leadership outcomes (as cited in Northouse, 2004).

The second approach, that is, the behavioral approach concentrates on what the leaders do and how they act. The researchers studying the behavioral approach put forward two types of behavior (Northouse, 2004). The first one is the task behavior in which it is important to achieve the goal. The second one is the relationship behavior in which 
the comfort of subordinates is important. Furthermore, managerial style approach of Blake and Mounton (1964) and X (authoritative)-Y (democratic) leadership theory of McGregor (1960) are other examples to the behavioral approach. On the other hand, Ohio State Studies and University of Michigan Studies examined behaviors of leaders. Ohio States Studies aimed to analyze how people act when they are leading a group. The researchers identified two dimensions of leader behavior. The first one was "initiating structure" which is related to task accomplishments. The second one was the "consideration" which is related to the relationship between the leaders and their followers. The University of Michigan Studies focused on the impact of the leaders' behaviors on the performance of small groups. The researchers identified two styles of leader behavior. One of them was the "production orientation" which gives importance to technical and production aspects of the job. The other was the "employee orientation" which gives importance to the strong human relations.

The third approach, that is, the situational approach criticized the first two approaches mentioned above in that that they were not comprehensive enough to reflect the complex nature of leadership. Therefore, it was claimed that leaders are effective when they can adapt their styles to different situations. Situational approach forms a basis for three theories. Firstly, Situational Theory was originated by Hersey and Blanchard (1969) and has been revised several times. According to this theory, leaders should recognize competence and commitment level of their subordinates in order to meet their needs (Northouse, 2004). Situational Theory is based on leadership styles and development levels of subordinates. Leadership style is related to the behavior patterns and categorized into two: directive and supportive behavior. In directive behaviors, leaders give instructions to accomplish their goals. On the other hand, supportive leaders socially and emotionally support their group members and make them feel comfortable. Secondly, Contingency Theory was constructed by Fiedler (1964) and is based on leader-match perspective. In other words, the theory asserts that leaders' effectiveness depends on how well their style fits the settings. The theory has three situational variables: leader-member relations, task structure, and position power. Leader-member relations include confidence, loyalty, and social attraction in terms of a positive group atmosphere. Task structure is related to the clarity of instructions or procedures. Position power refers to the leader's authority. These three situational factors together determine the favorableness of various situations. Thirdly, Path-Goal Theory formed a bridge between the styles of leader and the characteristics of subordinates and tasks. Underlying assumption of this theory was derived from the expectancy theory. According to this motivation theory, subordinates are motivated if they believe that they are performing well (Evans, 1970). The path-goal theory has four components (House \& Mitchel, 1974). The first component is related to the leader behavior including directive, supportive, participative, and achievement-oriented leadership. The second component is about the subordinate characteristics which determine how the subordinates interpret their leader's behavior. The third component is the task characteristics which are related to helping subordinates to overcome obstacles and compensate deficiencies in their abilities or working environment. The last component is motivation. Leadership style interacts with the characteristics of subordinates and tasks to influence the subordinates' motivation.

Contemporary theories have left their mark on a few last decades. Since the perspectives of contemporary theories differentiate from each other, it is difficult to gather them under an umbrella likewise the approaches above. For example, distributed leadership, strategic leadership, and instructional leadership focus on the shared responsibilities, vision and action, and improvement of school performance, respectively. On the other hand, there are more specific leadership theories. To name a few, emotional leadership, sustainable leadership, constructivist leadership, invitational leadership, and entrepreneurial leadership focus on narrower concepts (Lynch, 2012).

There are also some leadership approaches specific to the context of school or education. Taylor and Tashakkori (1994) found that principals' leadership influenced the school climate. According to Heck (1993), considering the educational accountability and change process in restructuring schools, principals' strategic interactions with teachers are important for managing the school, constructing a school climate, and setting an instructional organization. School principals are generally in schools so they should concentrate on instructional problems and produce solutions. In this aspect, a school principal should depict the behaviors of instructional leadership. Smith and Andrews (1989; as cited in Whitaker, 1997) determined four conditions for instructional leadership to ensure the student achievement. Firstly, school principals should provide the resources. The most important resource in the school is human, that is, teachers. Therefore, principals should recognize their teachers' weaknesses and strengths and pay attention to their needs and developments. Secondly, school principals should provide the needed resources for instructional purposes. Thirdly, administrators should clearly communicate with all staff to organize the educational settings. Lastly, school managers should be present everywhere.

Leadership behavior is essential for positive school outcomes. If the principals take more responsibility in framing, conveying, sustaining the goals of the school, then the school outcomes are influenced by these efforts (Hallinger $\&$ Heck, 1998). In regard to the context of the current study, academic achievement and teacher motivation, two 
core school outcomes, are closely related to leadership. According to Macneil, Prater, and Busch (2009), school principals should exhibit effective leadership to improve their students' performance by creating right relationships between themselves, teachers, students, and parents. Furthermore, Eyal and Roth (2011) found that the school principals' leadership style played a significant role on the motivation of teachers, and the power delegation and supportive autonomy increased their motivation.

\subsection{Purpose of the Study}

The current study aims to examine the leadership studies in the literature in order to test the effect of leadership styles on academic achievement and teacher motivation. A meta-analysis is performed to achieve this purpose. In this context, the research questions are as follows:

- How much do leadership styles affect academic achievement and teacher motivation?

- Do publication type, school level, instrument, and research region mediate the relationship between leadership styles and school outcomes?

\section{Method}

\subsection{Design of the Study}

The current study was designed as a meta-analysis. According to Littel, Corcoran, and Pillai (2008), meta-analysis is a method in which the findings of many independent studies are analyzed statistically. In the literature, reviews are generally carried out using one of the following three methods: critical synthesis based on systematic review, bibliometric analysis, and meta-analysis based on quantitative data (Hallinger, 2013; Hallinger, 2014). These methods are implemented in some steps. For example, Durlak (1995) offered the following steps: deciding on the research questions, reviewing the literature, coding the studies, forming an effect size index, analyzing the distribution of effect sizes, and presenting the results. The current study was carried out in line with the following steps.

\subsection{Search Criteria}

The research question was set on the relationship between leadership styles and academic achievement and teacher motivation. The inclusion and exclusion criteria were identified to select studies for the literature review part. Google Scholar, Council of Higher Education (CoHE-YÖK), and Turkish National Academic Network and Information Center (TNANAIC-ULAKBIM) databases were searched. The following keywords were searched for: leadership, school administration, student performance, academic achievement, and teacher motivation. Articles in the refereed journals, academic books, chapters in books, M.S. and Ph.D. theses, and reports in the last decade (2009-2019) in Turkish context were reviewed. The studies including qualitative data and other kinds of leadership like higher education or health institution leadership were excluded.

\subsection{Data Sources}

In order to determine the studies, PRISMA-P (Preferred Reporting Items for Systematic Reviews and Meta-analyses) developed by Moher, Liberati, Tetzlaff, Altman, and PRISMA Group (2009) was followed. This method has the steps of identification, screening, eligibility, and inclusion. Based on the search criteria described above, 28 studies were selected to show up in the identification step. Afterward, the studies were screened and 3 of them were excluded because they were related to the private course administration. Furthermore, 21 of the remaining 25 studies were found eligible in terms of the purpose of the current study since they were correlational studies with clear statistical values. Ultimately, 21 studies were included in the meta-analysis.

\subsection{Data Extraction and Analysis}

Coding is a data extracting method used to make the data clear and appropriate. After the review part, a coding form including the followings was created: reference of the study, type of the study, sample, data collection tools, methodological information, publication type, leadership style, education level, school level, study region, and statistical values. Effect size is an indicator showing the strength or magnitude and direction of a relationship. There are two models of effect size (Borenstein, Hedges, Higgins, \& Rothsteini, 2009). The first is the fixed effects model in which research is assumed same in terms of functionality, and effect size is valid only for the predetermined population. The second is the random effects model in which research is different in terms of functionality, and effect size is valid for making generalization on a bigger population. Due to the characteristics and conditions of the current study, the random effects model was used in the meta-analysis. Furthermore, since the studies were conducted in different publication types, at different school levels, by different scales, and in different regions; the moderator analysis was carried out using the variables of publication type, school level, instrument, and research region. Also, Comprehensive Meta-Analysis software was used in the study. 
To analyze the distribution of effect size, Pearson correlation coefficient (r) was determined as effect size. Based on Cohen's (1988) interpretation of effect sizes of correlation indices, the correlations around .10, .30, and .50 were evaluated as small, medium, and large effect sizes, respectively. On the other hand, since the correlations coefficient values changed between -1 and +1 , they were converted into $z$-value in order to make calculations and comparisons over Table z (Hedges \& Olkin, 1985). The exclusion/inclusion criteria, moderator analysis, and random effects model formed the basis for a valid and reliable meta-analysis. Furthermore, a funnel plot was drawn in order to check the publication bias.

\section{Results}

At the beginning of the meta-analysis, publication bias was checked using a funnel plot. Publication bias refers to an assumption that each study about a topic may not be published due to either non-significant results or small effect sizes. The funnel plot was drawn using the Meta-analysis software (Figure 1). In case of the violation of the publication bias, the funnel plot is expected to be not asymmetric and not intensified at the bottom of the funnel. As a result, no evidence was detected for partiality in the publications.

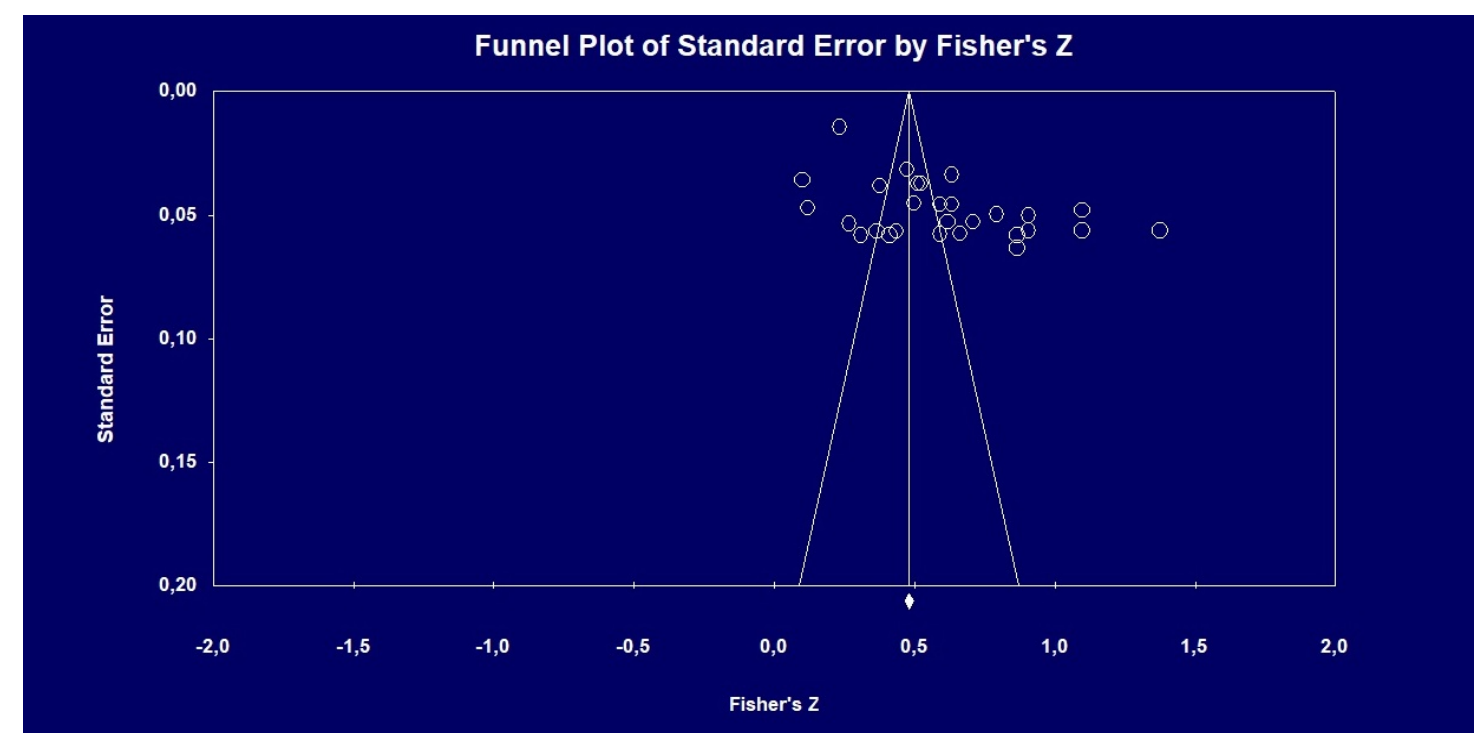

Figure 1. Funnel plot for publication bias

In spite of the violation of the publication bias in the shape, Duval and Tweedie's trim and fill test was conducted to check the partiality. Random effects model showed that there was no difference between the observed and adjusted value since the difference between the observed impact quantity and the artificial (adjusted) impact quantity was zero, which means that there is no lost data on both sides of the central line. The values related to trim and fill test were given in Table 1 .

Table 1. The Results of Duval and Tweedie's trim and fill

\begin{tabular}{|c|c|c|c|c|c|}
\hline \multirow{2}{*}{ Values } & \multirow{2}{*}{ Imputed (left) } & \multirow{2}{*}{ Point estimate } & \multicolumn{2}{|c|}{ CI } & \multirow{2}{*}{ Q } \\
\hline & & & $L L$ & $U L$ & \\
\hline Observed & & .54 & .46 & .61 & 1369.33 \\
\hline Adjusted & 0 & .54 & .46 & .61 & 1369.33 \\
\hline
\end{tabular}

The current study examined 21 studies in order to show the relation of the leadership styles with school outcomes. Since some of the studies included more than one leadership styles, there were 28 subgroups. The total number of the individuals who participated in the studies was 14409 participants. More than half of the studies were published in the years of $2010(n=4), 2016(n=4), 2015(n=3)$, and $2018(n=3)$. Most of the studies concentrated on the transformational $(n=5)$, transactional $(n=4)$, and instructional $(n=4)$ leadership styles while the others on the positive $(n=1)$, servant $(n=1)$, school $(n=1)$, authoritative $(n=1)$, and spiritual $(n=1)$ 
leadership styles. In addition, the transformational, transactional, distributed, instructional, laissez-faire, and supportive leadership styles appeared in the studies of both motivation and achievement. The information about the selected studies is given in Table 2 .

Table 2. Characteristics of the selected studies for meta-analysis

\begin{tabular}{|c|c|c|c|c|}
\hline Study & Year & Leadership Style & School Outcome & Sample Size \\
\hline MA1 & 2010 & Collaborative & Academic achievement & 452 \\
\hline MA1 & 2010 & Collaborative & Academic achievement & 784 \\
\hline MA3 & 2010 & Supportive & Academic achievement & 683 \\
\hline MA4 & 2009 & Positive & Academic achievement & 400 \\
\hline MA5 & 2018 & $\begin{array}{c}\text { Transformational } \\
\text { Laissez-Faire } \\
\text { Transactional }\end{array}$ & Academic achievement & 298 \\
\hline MA6 & 2015 & Distributed & Academic achievement & 352 \\
\hline MA7 & 2015 & $\begin{array}{c}\text { Transformational } \\
\text { Transactional }\end{array}$ & Academic achievement & 363 \\
\hline MA8 & 2015 & Instructional & Academic achievement & 4848 \\
\hline MA9 & 2012 & $\begin{array}{c}\text { Supportive } \\
\text { Authoritative }\end{array}$ & Teacher motivation & 723 \\
\hline MA10 & 2010 & $\begin{array}{l}\text { Transactional } \\
\text { Laissez-Faire }\end{array}$ & Teacher motivation & 317 \\
\hline MA11 & 2017 & Authentic & Teacher motivation & 882 \\
\hline MA12 & 2013 & Instructional & Teacher motivation & 318 \\
\hline MA13 & 2013 & Spiritual & Teacher motivation & 252 \\
\hline MA14 & 2017 & Distributed & Teacher motivation & 1000 \\
\hline MA15 & 2018 & $\begin{array}{c}\text { Transformational } \\
\text { Servant }\end{array}$ & Teacher motivation & 314 \\
\hline MA16 & 2018 & Authentic & Teacher motivation & 436 \\
\hline MA17 & 2016 & Transformational & Teacher motivation & 493 \\
\hline MA18 & 2016 & Instructional & Teacher motivation & 305 \\
\hline MA19 & 2016 & $\begin{array}{c}\text { Transformational } \\
\text { Transactional }\end{array}$ & Teacher motivation & 480 \\
\hline MA20 & 2009 & Instructional & Teacher motivation & 406 \\
\hline \multirow[t]{2}{*}{ MA21 } & 2016 & School & Teacher motivation & 303 \\
\hline & & & & 14409 \\
\hline
\end{tabular}

In line with the random effects model, the meta-analysis was run on the studies. The meta-analysis showed that the leadership styles had a large effect on the school outcomes including teacher motivation and academic achievement. According to the random effects model, there was a positive relationship $(r=.54)$ between leadership style and school outcomes. Especially, leadership had a high relation with teacher motivation $(r=.61)$, but a moderate relation with academic achievement $(r=.42)$. Findings of the meta-analysis are shown in the Table 3 .

Table 3. Meta-analysis of relationship between leadership styles and school outcomes

\begin{tabular}{lccc}
\hline Leadership Style & Teacher Motivation & Academic Achievement & School Outcomes \\
\hline Instructional & .65 & .23 & .57 \\
Transformational & .46 & .62 & .54 \\
Transactional & .65 & .45 & .59 \\
Distributed & .44 & .26 & .36 \\
Servant & .41 & - & .41 \\
Collaborative & - & .11 & .11 \\
Authentic & .70 & - & .70 \\
Spiritual & .70 & - & .70 \\
Supportive & .47 & .36 & .42 \\
Authoritative & .48 & - & .48 \\
\hline
\end{tabular}




\begin{tabular}{lccc}
\hline Positive & - & .72 & .72 \\
School & .53 & - & .53 \\
Laissez-Faire & .88 & .39 & .71 \\
Total Leadership & .61 & .42 & .54 \\
\hline
\end{tabular}

Teacher motivation had a high relationship with the following leadership styles in order of high to low: laissez-faire $(\mathrm{r}=.88)$, spiritual $(\mathrm{r}=.70)$, authentic $(\mathrm{r}=.70)$ instructional $(\mathrm{r}=.65)$, transactional $(\mathrm{r}=.65)$, and school $(\mathrm{r}=.53)$. Despite the moderate effect size, the authoritative $(\mathrm{r}=.48)$, supportive $(\mathrm{r}=.47)$, transformational $(\mathrm{r}$ $=.46)$, distributed $(\mathrm{r}=.44)$, and servant $(\mathrm{r}=.41)$ leadership styles had the least effect on teacher motivation. On the other hand, academic achievement was related mostly to the positive $(r=.72)$ and transformational leadership ( $\mathrm{r}$ $=.62)$. The collaborative $(\mathrm{r}=.11)$, instructional $(\mathrm{r}=.23)$, and distributed $(\mathrm{r}=.26)$ leadership styles had the least effect on academic achievement while the supportive $(\mathrm{r}=.36)$ and transactional $(\mathrm{r}=.45)$ leadership styles had a medium effect on academic achievement.

Moderator analysis was conducted to respond the second research question. The analysis showed that the difference of effect between school levels $(\mathrm{Qb}=1.92, \mathrm{p}>.05)$ and instruments $(\mathrm{Qb}=.05, \mathrm{p}>.05)$ was not found to be statistically significant whereas that between publication types $(\mathrm{Qb}=5.83, \mathrm{p}<.05)$ and regions $(\mathrm{Qb}=29.25, \mathrm{p}$ $<.05$ ) were found to be statistically significant. In other words, only the publication type and region were the moderator variables for the relation between leadership styles and school outcomes. Table 4 summarizes the moderator analysis of the meta-analysis.

Table 4. Meta-analysis in terms of moderator analysis

\begin{tabular}{|c|c|c|c|c|c|c|c|}
\hline \multirow{2}{*}{ Variables } & \multirow{2}{*}{$\mathrm{K}$} & \multirow{2}{*}{$\mathrm{r}$} & \multicolumn{2}{|c|}{ CI } & \multirow{2}{*}{ Q } & \multirow{2}{*}{$\mathrm{Q}_{\mathrm{b}}$} & \multirow{2}{*}{$\mathrm{p}$} \\
\hline & & & LL & $\mathrm{UL}$ & & & \\
\hline Leadership & 28 & $.54 *$ & .47 & .61 & 1369.33 & & \\
\hline Publication type & & & & & & 5.83 & .02 \\
\hline These & 19 & $.47 *$ & .46 & .48 & & & \\
\hline Article & 9 & $.40 *$ & .38 & .42 & & & \\
\hline School level & & & & & & 1.92 & .38 \\
\hline Elementary & 17 & $.43 *$ & .42 & .45 & & & \\
\hline High school & 4 & $.49^{*}$ & .45 & .53 & & & \\
\hline All & 7 & $.48^{*}$ & .45 & .51 & & & \\
\hline Instrument & & & & & & .05 & .82 \\
\hline Adapted & 21 & $.43 *$ & .42 & .45 & & & \\
\hline Developed & 7 & $.53 *$ & .50 & .56 & & & \\
\hline Region & & & & & & 29.25 & .00 \\
\hline Mediterranean & 2 & $.38 *$ & .31 & .45 & & & \\
\hline East & 5 & $.42 *$ & .39 & .45 & & & \\
\hline Aegean & 3 & $.79 *$ & .76 & .81 & & & \\
\hline South-east & 5 & $.56^{*}$ & .53 & .59 & & & \\
\hline Central Anatolia & 4 & $.29 *$ & .27 & .31 & & & \\
\hline Black Sea & 3 & $.52 *$ & .48 & .55 & & & \\
\hline Marmara & 4 & $.62 *$ & .58 & .65 & & & \\
\hline All & 2 & $.42 *$ & .36 & .47 & & & \\
\hline
\end{tabular}

\section{Discussion}

The current study showed that leadership had a strong relationship $(\mathrm{r}=.54)$ with school outcomes. This finding is consistent with those reached in both the meta-analysis studies in the Turkish literature (Çoğaltay, Karadağ, \& Öztekin, 2014; Çoğaltay, Yalçın, \& Karadağ, 2016; Sarıer, 2013; Ünal, 2017) and the international studies (Eyal \& Roth, 2011; Jacobson, 2011, Ross \& Gray, 2006; Sun \& Leithwood, 2012). There is serious evidence that school principals' leadership style has an effect on positive school outcomes. Chin (2007) conducted a meta-analysis in the contexts of Taiwan and US and found that transformational leadership had a positive effect on school effectiveness, teacher satisfaction, and student achievement. Robinson, Lloyd, and Rowe (2008) carried out a study on the leadership styles such as transformational, instructional leadership, etc. in a variety of countries from 
US to New Zealand. Their meta-analysis showed that instructional leadership had more effect on student outcomes than transformational leadership and other leadership styles. Furthermore, Witziers, Bosger, and Krüger (2003) found a positive relationship between school leadership and student performance.

The current study put forward a contrarian and interesting finding in that there was a strong positive relationship between the laisses-faire leadership style and the school outcomes. Although laissez-faire leadership is a kind of absent leadership, this style showed positive effects on school outcomes. Therefore, this finding is not common for the literature concentrating on other outcomes. For example, Cemaloğlu (2007) investigated the relationship between leadership and mobbing and found that there was a negative relationship between laissez-faire and positive outcomes like intellectual stimulation and support, and a positive relationship between laissez-faire and mobbing. The reason why the laissez-faire style improved the school outcomes may be the contextual factors such as attitude of teachers, expectations of students, and structure of school management. On the other hand, the instructional, transformational, and transactional leadership styles had large effect sizes while the distributed and supportive leadership styles had moderate effect sizes. These findings are in line with the international literature. The study by Shatzer, Calderella, and Hallam (2014) showed that both instructional and transformational leadership improved the student achievement. Moreover, Dumdum, Lowe, and Avolio (2002) found that transformational and transactional leadership had a positive effect on effectiveness and satisfaction. The literature on distributed leadership has two gaps (Bennett, Wise, Woods, \& Harvey, 2003). One of them is related to the conceptualization of the theory while the other is related to the empirical applicability. Tian, Risku, and Collin (2016) investigated whether these gaps were filled and concluded that these gaps could not be filled satisfactorily. So, the current study drew a picture similar to the literature in terms of distributed leadership.

Moreover, a strong relationship $(r=.61)$ was found to exist between leadership and motivation. This finding is consistent with the literature. Thoonen, Sleegers, Oort, Peetsma, and Geijsel (2011) examined the improvement of teacher practices and found that transformational leadership was related to teacher motivation. Similarly, the study by Ünal (2017) showed a high level of relation between transformational leadership and teacher motivation. On the other side, there was a medium relationship $(\mathrm{r}=.42)$ between leadership and academic achievement. This finding is parallel to the findings of other studies. Louis, Dretzke, and Wahlstrom (2010) investigated the effect of leadership on student achievement and found that shared and instructional leadership styles increased the student achievement. Moreover, the study by Boberg and Bourgeois (2016) revealed that transformational leadership affected the student performance in courses. In his meta-analysis study, Sarier (2013) found a high correlation between supportive leadership and academic achievement of student.

The current meta-analysis study provides important insights into the leadership in the Turkish context in terms of research, practice, ad theory. First of all, the current study asserts that leadership is closely related to school outcomes. Laissez-faire, instructional, transformational, and transactional leadership styles drew attention; so, researchers may investigate common aspects of these styles in the Turkish context. Improving the leadership practices will increase the teacher motivation and the students' academic success. For this reason, it is recommended that school principals and policy-makers implement leadership practices. These practices should be organized for both administrators and teachers. In terms of theory, the findings of the current study may be the first step in developing a leadership theory specific to Turkish educational context. The theories studied in Turkey such as transformational, instructional, and distributed leadership are adapted or borrowed from other contexts. Therefore, there is a need for an original leadership theory for schools in Turkey. Model or theory developers should consider the core aspects of each theory with a holistic approach. On the other hand, teacher motivation had the highest relation with laissez-faire leadership style. This may imply that teachers do not prefer to be led by school principals for their work loads.

Recommendations of this study are intended for researchers, practitioners, and theorists. The current study was based on teacher motivation and academic achievement. The researcher of the study aimed at including a family variable in the meta-analysis, but could not find one. In addition to the teacher and student outcomes, the family outcomes like parent involvement should be examined in future for leadership practices. Moreover, some leadership styles were studied with limited concepts. For example, authentic leadership was frequently studied with teacher motivation, but there was no quantitative study examining it with academic achievement in the literature. Therefore, researchers should investigate leadership approaches with more school outcomes. Practitioners should be aware of the influences of leadership on school outcomes. They should care about behaviors compatible with positive leadership styles. Investigation of the reason why laissez-faire was more dominant for teacher motivation and academic achievement by theorists is valuable for the purpose of the current study. The study aimed at showing the most dominant leadership style on school outcomes. However, surprisingly, laissez-faire leadership was the most dominant overall. In addition, it had a high relation with teacher motivation 
and a medium relation with academic achievement. Therefore, theorists should examine this variation and differentiation.

\section{References}

Altay, H., \& Dedeoğlu, B. (2016). Etik liderlik ve örgütsel vatandaşlik davranişi arasindaki ilişkide örgütsel sinizm ve işe yabancilaşmanin aracilik rolü: Antakya turizm sektörü çalişanlari örneği. Balkan Sosyal Bilimler Dergisi, 458-474.

Aydın, A., Sarıer, Y., \& Uysal, Ş. (2013). The effect of school principals' leadership styles on teachers' organizational commitment and job satisfaction. Educational Sciences: Theory and Practices, 13(2), 806-811

Baloğlu, N. (2016). Okul müdürlerinin dağitimci liderlik davranişlari ile kişilik özellikleri arasindaki ilişkiler. Kastamonu Ĕ̈itim Dergisi, 24(4), 1853-1866.

Barro, R. J. (2013). Education and economic growth. Annals of Economics and Finance, 14(2), 277-304.

Bennett, N., Wise, C., Woods, P., \& Harvey, J. (2003). Distributed leadership: Full report. Nottingham, UK: National College for School Leadership.

Boberg, J. E., \& Bourgeois, S. J. (2016). The effects of integrated transformational leadership on achievement. Journal of Educational Administration, 54(3), 357-374. https://doi.org/10.1108/jea-07-2014-0086

Borenstein, M., Hedges, L. V., Higgins, J. P. T., \& Rothstein, H. R. (2009). Introduction to Meta-analysis. UK: Wiley. https://doi.org/10.1002/9780470743386

Cemaloğlu, N. (2007). Okul yöneticilerinin liderlik stilleri ile yıldırma arasındaki ilişki. Hacettepe Üniversitesi Ĕgitim Fakültesi Dergisi, 33(33), 77-87.

Cheng Y. C., \& Tam, W. M. (1997). Multi-models of quality in education. Quality Assurance in Education, 5(1), 22-31. https://doi.org/10.1108/09684889710156558

Chin, J. M. C. (2007). Meta-analysis of transformational school leadership effects on school outcomes in Taiwan and the USA. Asia Pacific Education Review, 8(2), 166-177. https://doi.org/10.1007/bf03029253

Çoğaltay, N., Karadağ, E., \& Öztekin, Ö. (2014). Okul müdürlerinin dönüşümcü liderlik davranışlarının öğretmenlerin örgütsel bağlı̆lı̆ı̆na etkisi: Bir meta-analiz çalışması. Kuram ve Uygulamada Egitim Yönetimi Dergisi, 20(4), 483-500. https://doi.org/10.14527/kuey.2014.019

Çogaltay, N., Yalçın, M., \& Karadağ, E. (2016). Educational leadership and job satisfaction of teachers: A meta-analysis study on the studies published between 2000 and 2016 in Turkey. Eurasian Journal of Educational Research, 16(62), 255-282. https://doi.org/10.14689/ejer.2016.62.13

Cohen, J. (1988). Statistical power analysis for the behavioral sciences. Hillside, NJ: Lawrence Erlbaum Associates

Connelly, M. S., Gilbert, J. A., Zaccaro, S. J., Threlfall, K. V., Marks, M. A., \& Mumford, M. D. (2000). Exploring the relationship of leadership skills and knowledge to leader performance. Leadership Quarterly, 11(1), 65-86. https://doi.org/10.1016/s1048-9843(99)00043-0

Demirdağ, S. (2015). Otantik liderlik ve örgütsel vatandaşlık davranışlarının karşılaştırılması: Öğretmen adayları. Electronic Turkish Studies, 10(15), 273-288. https://doi.org/10.7827/turkishstudies.8747

Demirdağ, S. (2016). İlkokul yöneticilerinin etik liderlik davranışları ile çatışma yönetimi stratejileri arasındaki ilişki: Ücretli öğretmen görüş̧leri. Electronic Turkish Studies, 11(3), 879-894. https://doi.org/10.7827/TurkishStudies.9250

Dumdum, U. R., Lowe, K. B., \& Avolio, B. J. (2013). A meta-analysis of transformational and transactional leadership correlates of effectiveness and satisfaction: An update and extension. In Transformational and Charismatic Leadership: The Road Ahead 10th Anniversary Edition (pp. 39-70). Emerald Group Publishing Limited. https://doi.org/10.1108/S1479-357120130000005008

Durlak, J. A. (1995). Understanding meta-analysis. In L. G. Grimm, \& P. R. Yarnold (Eds.), Reading and understanding multivariate statistics (pp. 319-352). Washington, DC, US: American Psychological Association.

Elekoğlu, F., \& Demirdağ, S. (2020). Okul müdürlerinin 21. yüzyıl becerileri, iletişim becerileri ve liderlik stillerinin öğretmen algılarına göre incelenmesi. Karaelmas Eğitim Bilimleri Dergisi, 8(1), 101-117. 
Erdoğan, B., Kraimer, M. L., \& Liden, R. C. (2004). Work value congruence and intrinsic career success: The compensatory roles of leader-member exchange and perceived organizational support. Personnel Psychology, 57, 305-332. https://doi.org/10.1111/j.1744-6570.2004.tb02493.x

Evans, M. G. (1970). The effects of supervisory behavior on the path-goal relationship. Organizational Behavior and Human Performance, 5(3), 277-298. https://doi.org/10.1016/0030-5073(70)90021-8

Eyal, O., \& Roth, G. (2011). Principals' leadership and teachers' motivation: Self-determination theory analysis. Journal of Educational Administration, 49(3), 256-275. https://doi.org/10.1108/09578231111129055

Fiedler, F. E. (1964). A contingency model of leadership effectiveness. Advances in Experimental Social Psychology, 1(1964), 149-190. https://doi.org/10.1016/s0065-2601(08)60051-9

Gedikoğlu, T. (2005). Avrupa Birliği sürecinde türk eğitim sistemi: sorunlar ve çözüm önerileri. Mersin Üniversitesi Ĕ̈itim Fakültesi Dergisi, 1(1), 66-80.

Hallinger, P. (2013). A conceptual framework for systematic reviews of research in educational leadership and

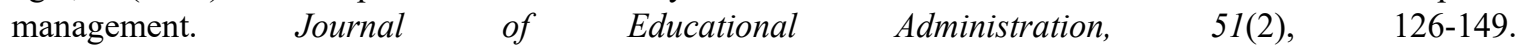
https://doi.org/10.1108/09578231311304670

Hallinger, P. (2014). Reviewing reviews of research in educational leadership: An empirical assessment. Educational Administration Quarterly, 50(4), 539-576. https://doi.org/10.1177/0013161x13506594

Hallinger, P., \& Heck, R. H. (1998). Exploring the principal's contribution to school effectiveness: 1980-1995. School Effectiveness and School Improvement, 9(2), 157-191. https://doi.org/10.1080/0924345980090203

Heck, R. H. (1993). School context, principal leadership, and achievement: The case of secondary schools in Singapore. The Urban Review, 25(2), 151-166. https://doi.org/10.1007/bf01137796

Hedges, L. V., \& Olkin, I. (1985). Statistical method for meta-analysis. UK: Academic Press.

Hersey, P., \& Blanchard, K. H. (1969). Life cycle theory of leadership. Training \& Development Journal, 23(5), $26-34$.

House R. J., \& Mitchell, T. R. (1974). Path-goal theory of leadership. Organizational research, University of Washignton, Seattle. Retrieved from https://apps.dtic.mil/sti/pdfs/ADA009513.pdf

Jacobson, S. (2011). Leadership effects on student achievement and sustained school success. International Journal of Educational Management, 25(1), 33-44. https://doi.org/10.1108/09513541111100107

Keung, E. K., \& Rockinson-Szapkiw, A. J. (2012). The relationship between transformational leadership and cultural intelligence. Journal of Educational Administration, 51(6), 836-854. https://doi.org/10.1108/JEA-04-2012-0049

Littell, J. H., Corcoran, J., \& Pillai, V. (2008). Systematic reviews and meta-analysis. Oxford University Press. https://doi.org/10.1093/acprof:oso/9780195326543.001.0001

Louis, K. S., Dretzke, B., \& Wahlstrom, K. (2010). How does leadership affect student achievement? Results from a national US survey. School Effectiveness and School Improvement, 21(3), 315-336. https://doi.org/10.1080/09243453.2010.486586

Lynch, M. (2012). A guide to effective school leadership theories. New York and London: Routledge. https://doi.org/10.4324/9780203181010

Macneil A. J., Prater, D. L., \& Bush, S. (2009). The effects of school culture and climate on student achievement. Int. J. Leadership in Education, 12(1), 73-84. https://doi.org/10.1080/13603120701576241

Moher, D., Liberati, A., Tetzlaff, J., Altman, D. G., \& Prisma Group. (2009). Preferred reporting items for systematic reviews and meta-analyses: the PRISMA statement. PLoS Med, 6(7), e1000097. https://doi.org/10.1371/journal.pmed.1000097

Moss, J. A., \& Barbuto Jr, J. E. (2010). Testing the relationship between interpersonal political skills, altruism, leadership success and effectiveness: A multilevel model. Journal of Behavioral \& Applied Management, $11(2), 155-174$.

Northouse, P. G. (2004). Leadership: theory and practice. London: SAGE

Organization for Economic Cooperation and Development. (2017). Education Policy Outlook: Turkey.

Preedy, M., Bennett, N., \& Wise, C. (Eds.). (2011). Educational Leadership: Context, Strategy and Collaboration. California: Sage. https://doi.org/10.4135/9781473915244 
Robinson, V. M., Lloyd, C. A., \& Rowe, K. J. (2008). The impact of leadership on student outcomes: An analysis of the differential effects of leadership types. Educational Administration Quarterly, 44(5), 635-674. https://doi.org/10.4135/9781473915152.n6

Ross, J. A., \& Gray, P. (2006). School leadership and student achievement: The mediating effects of teacher beliefs. Canadian Journal of Education, 29(3), 798-822. https://doi.org/10.2307/20054196

Sarıer, Y. (2013). Eğitim kurumu müdürlerinin liderliği ile okul çıktıları arasındaki ilişkilerin meta-analiz yöntemiyle incelenmesi (Unpublished doctoral thesis). Eskişehir Osmangazi University, Eskişehir, Turkey.

Schuh, S. C., Zhang, X., \& Tian, P., (2013). For the good or the bad? interactive effects of transformational leadership with moral and authoritarian leadership behavior. Journal of Business Ethics, 116, 629-640. https://doi.org/10.1007/s10551-012-1486-0

Shatzer, R. H., Caldarella, P., Hallam, P. R., \& Brown, B. L. (2014). Comparing the effects of instructional and transformational leadership on student achievement: Implications for practice. Educational Management Administration \& Leadership, 42(4), 445-459. https://doi.org/10.1177/1741143213502192

Şisman, M. (2016). Factors related to instructional leadership perception and effect of instructional leadership on organizational variables: a meta-analysis. Educational Sciences: Theory and Practice, 16(5), 1761-1787. https://doi.org/10.12738/estp.2016.5.0172

Sun, J., \& Leithwood, K. (2012). Transformational school leadership effects on student achievement. Leadership and Policy in Schools, 11(4), 418-451. https://doi.org/10.1080/15700763.2012.681001

Taylor, D. L., \& Tashakkori, A. (1994). Predicting teachers' sense of efficacy and job satisfaction using school climate and participatory decision making. Paper presented at the annual meeting of Southwest Research Association.

Thoonen, E. E., Sleegers, P. J., Oort, F. J., Peetsma, T. T., \& Geijsel, F. P. (2011). How to improve teaching practices: The role of teacher motivation, organizational factors, and leadership practices. Educational Administration Quarterly, 47(3), 496-536. https://doi.org/10.1177/0013161x11400185

Tian, M., Risku, M., \& Collin, K. (2016). A meta-analysis of distributed leadership from 2002 to 2013: Theory development, empirical evidence and future research focus. Educational Management Administration \& Leadership, 44(1), 146-164. https://doi.org/10.1177/1741143214558576

Ünal, S. (2017). Dönüşümcü liderliğin örgütsel çıktılara etkisi: bir meta-analiz çalışması (Unpublished doctoral thesis). Eskişehir Osmangazi University, Eskişehir, Turkey.

Whitaker, B. (1997). Instructional leadership and principal visibility. The Clearing House: A Journal of Educational Strategies, Issues and Ideas, 70(3), 155-156. https://oi.org/10.1080/00098655.1997.10543916

Witziers, B., Bosker, R. J., \& Krüger, M. L. (2003). Educational leadership and student achievement: The elusive search for an association. Educational Administration Quarterly, 39(3), 398-425. https://doi.org/10.1177/0013161x03253411

\section{Copyrights}

Copyright for this article is retained by the author(s), with first publication rights granted to the journal.

This is an open-access article distributed under the terms and conditions of the Creative Commons Attribution license (http://creativecommons.org/licenses/by/4.0/). 